\title{
CD8-positive memory T cells in tumor- draining lymph nodes of patients with breast cancer
}

\author{
Yasmin Vahidi ${ }^{1}$, Mandana Bagheri ${ }^{2}$, Abbas Ghaderi $^{1}$ and Zahra Faghih $^{1 *}$
}

\begin{abstract}
Background: Human immunological memory is a hallmark of the adaptive immune system and plays an important role in the development of effective immune responses against tumors. In the present study, we aimed to determine the frequencies of $\mathrm{CD}^{+}$memory T cell subsets including T stem cell memory (TSCM) in tumor-draining lymph nodes of patients with breast cancer (BC).

Methods: Mononuclear cells were obtained from axillary lymph nodes of 52 untreated patients with $B C$ and stained for CD8, CCR7, CD45RO, CD95 markers to detect different subtypes of memory cells in the CD8 ${ }^{+}$ lymphocyte population. Data were acquired on four-color flow cytometer and analyzed with CellQuest Pro software.

Results: We observed that $47.65 \pm 2.66 \%$ of $C D 8^{+}$lymphocytes expressed the CD45RO, a marker for memory $T$ cells. Statistical analysis showed that the total frequency of central memory T cells (TCM) and their subset with low CD45RO expression was significantly higher in tumor-involved nodes compared to tumor-free ones $(P=0.024$ and $P=0.017$, respectively). The level of CD95 expression (based on mean fluorescence intensity) on the surface of TCM, their CD45RO hi and CD45RO low subsets, and TSCM was higher in patients with stage II compared to those in stage I $(P<0.05)$. In addition, the percentage of naive $C D 8^{+} T$ cells was significantly lower in tumor-involved lymph nodes compared to tumor-free ones $(P=0.025)$.

Conclusions: Our data collectively indicate no significant differences in the frequencies of $\mathrm{CD}^{+}{ }^{+}$lymphocytes or their memory subsets in tumor-draining lymph nodes of patients with BC. However, the frequency of CD $45^{\text {low }}$ TCM was higher in tumor-involved nodes. Along with a decrease in the frequency of naive T cells, the higher frequency of $C D 45^{\text {low }}$ TCM suggests that despite the immune reaction to provide a pool of effective memory cells, it is blocked in early-stage of memory cells' differentiation $\left(C D 45 R O^{\text {low }}\right)$, probably by tumor-derived suppressive factors. Identifying the molecular and cellular mechanisms behind this suppression can provide invaluable tools for adoptive $T$ cell therapies in cancer.
\end{abstract}

Keywords: Breast cancer, Lymph node, CD8 ${ }^{+}$memory subsets, Memory stem cells

\footnotetext{
* Correspondence: faghihz@sums.ac.ir

${ }^{1}$ Shiraz Institute for Cancer Research, School of Medicine, Shiraz University of Medical Sciences, P.O. Box: 71345-1798, Shiraz, Iran

Full list of author information is available at the end of the article
}

(c) The Author(s). 2020 Open Access This article is licensed under a Creative Commons Attribution 4.0 International License, which permits use, sharing, adaptation, distribution and reproduction in any medium or format, as long as you give appropriate credit to the original author(s) and the source, provide a link to the Creative Commons licence, and indicate if changes were made. The images or other third party material in this article are included in the article's Creative Commons licence, unless indicated otherwise in a credit line to the material. If material is not included in the article's Creative Commons licence and your intended use is not permitted by statutory regulation or exceeds the permitted use, you will need to obtain permission directly from the copyright holder. To view a copy of this licence, visit http://creativecommons.org/licenses/by/4.0/. The Creative Commons Public Domain Dedication waiver (http://creativecommons.org/publicdomain/zero/1.0/) applies to the data made available in this article, unless otherwise stated in a credit line to the data. 


\section{Background}

Human immunological memory, a hallmark of the adaptive immune system, plays an important role in limiting the severity of infection and preventing morbidity [1]. For $\mathrm{T}$ lymphocytes, long-lasting immune protection is achieved by the differentiation of naive $\mathrm{T}$ cells upon antigen stimulation into distinct memory cell lineages: central (TCM) and terminally committed effector memory $\mathrm{T}$ cells (TEM). These cells are characterized by selfrenewal capacity, clonal expansion, and faster attainment of effector functions upon antigen re-stimulation or challenge [2]. The repertoire of memory $\mathrm{T}$ cells was recently extended to diverse subtypes characterized by specific cell surface markers, unique homing properties, and special functional attributes [3].

$\mathrm{T}$ stem cells memory (TSCMs) were recently introduced as a rare subset of memory lymphocytes with the stem cell-like ability to self-renew and provide other memory and effector subsets [4-6]. Although these cells express naive markers they are more similar to memory subsets in function, as they express CD95 memory antigen and are antigen-experienced cells that respond rapidly to secrete effector cytokines [2]. These capabilities, along with recent evidence of their potential role in immune reconstitution in immunodeficient hosts and ability to mediate superior antitumor immunity in humanized mouse models, have brought TSCM cells to the attention of researchers in immunity and immunotherapies [7-9]. However, their role in tumor development and progression remains poorly understood [10].

In growing tumors, tumor-infiltrating lymphocytes have been shown to mediate an effective antitumor response. Among $\mathrm{T}$ cell subsets, $\mathrm{CD} 8^{+}$cells have been widely studied in cancer due to their ability to directly kill transformed cells $[10,11]$. However, the suppressive tumor microenvironment often impairs their functionality through a set of transcriptional, functional, and phenotypic changes $[10,12]$. Thus the present study, to extend our previous work on memory cells in tumors $[13,14]$, was designed to investigate the role of $\mathrm{CD}^{+}$lymphocytes and their memory cell subsets in tumor-draining lymph nodes (TDLNs) of patients with breast cancer (BC), and to identify their associations with clinical and pathological features.

\section{Methods}

\section{Patients}

Axillary lymph nodes (LNs) were obtained from 52 patients with $\mathrm{BC}$ who had undergone surgery for tumor resection. None of the patients had a history of chemotherapy or radiotherapy before surgery. A fresh part of each axillary LN was used for immunological assays, and the remaining tissue was used for routine pathological examination. Tumor infiltration into the nodes was determined histologically by pathologists. Nodes that were infiltrated by tumor cells were classified as node-positive $(\mathrm{LN}+)$. Patients were considered $\mathrm{LN}_{+}$if at least one resected regional lymph node was observed to be infiltrated by tumor cells. Clinical and pathological information was obtained from the patients' medical records. Their disease stage was determined with the TNM staging system according to the 7th edition of the AJCC cancer staging manual [15].

\section{Isolation of mononuclear cells from lymph nodes}

To obtain a homogenous cell suspension, fresh LNs were mechanically minced into small pieces in complete culture medium [RPMI 1640 (Biosera, France)] containing $10 \%$ fetal bovine serum (FBS, Gibco, USA), 100 units $/ \mathrm{ml}$ penicillin, and $100 \mu \mathrm{g} / \mathrm{ml}$ streptomycin (Biosera, France), and filtered through a $40-\mu \mathrm{m}$ cell strainer (BD Biosciences, USA). Mononuclear cells were then isolated by centrifugation over a Ficoll-Hypaque density gradient (Biosera, France). The mononuclear ring was harvested and washed twice, and dissolved in $1 \times$ phosphate-buffered saline (PBS) for further analysis. To determine the number of viable cells, the Trypan Blue dye (Biosera, France) exclusion test was used. Then cells at a concentration of $250 \times 10^{3}$ in $50 \mu \mathrm{l} 1 \times \mathrm{PBS}$ were distributed in round-bottomed polystyrene flow cytometry tubes (BD Biosciences, USA) for further analysis.

\section{Flow cytometry analysis \\ Antibodies}

To determine the phenotype of memory $\mathrm{T}$ cell subsets, we used the following anti-human antibodies: FITC-antiCCR7 (3D12), PE-anti-CD95 (Dx2), APC-conjugated antiCD45RO (UCHL1), and PerCP anti-CD8 (Sk1), and their respective isotype controls: FITC-conjugated mouse IgG2a, PE-conjugated mouse IgG1, APC-conjugated mouse IgG2a, and PerCP-conjugated mouse IgG1 (all from BD Biosciences, USA).

\section{Cell staining}

The mononuclear cells were surface-stained with appropriate fluorochrome-conjugated antibodies for $20 \mathrm{~min}$ at room temperature. The cells were then washed twice with $1 \times$ PBS to remove unbound antibodies, and analyzed with a four-color FACSCalibur flow cytometer (BD Biosciences, USA).

\section{Flow cytometry data analysis}

Flow cytometry data were analyzed with CellQuest Pro software (BD Biosciences, USA). Dead cells were first excluded according to their forward and side scatter (Fig. 1a). To determine the frequency of different memory $T$ cell subsets, after selecting $\mathrm{CD}^{+}$cells in the lymphocytes gate (Fig. 1b), the phenotype of different subsets was 


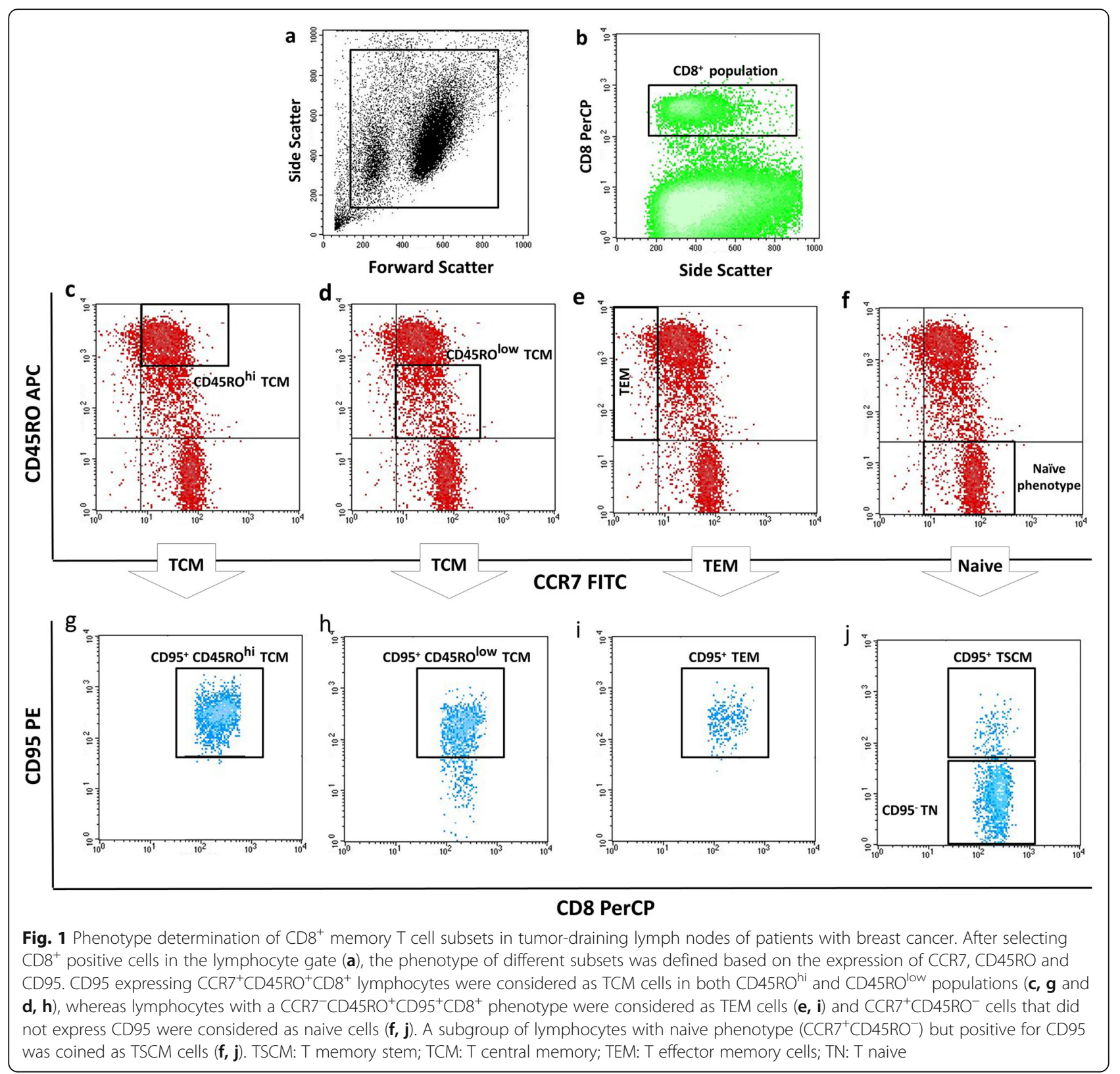

defined based on the expression of CCR7, CD45RO, and CD95. Those $\mathrm{CD} 95^{+} \mathrm{CD} 8^{+}$lymphocytes which expressed both CCR7 and CD45RO simultaneously, were considered TCM cells (Fig. 1c, d, g and h); the population with a $\mathrm{CCR}^{-} \mathrm{CD} 45 \mathrm{RO}^{+} \mathrm{CD} 95^{+} \mathrm{CD}^{+}$phenotype was considered TEM cells (Fig. 1e and i); and $C C R 7^{+} \mathrm{CD} 45 \mathrm{RO}^{-}$cells that did not express CD95 were considered naive T cells (Fig. If and $\mathrm{j}$ ). A subgroup of cells with the naive phenotype $\mathrm{CCR}^{+}{ }^{+} \mathrm{CD} 45 \mathrm{RO}^{-}-$but positive for $\mathrm{CD} 95$ were considered TSCM cells (Fig. If and j). CD45RO expression on TCM cells was variable, so we divided these cells into $\mathrm{CD} 45 \mathrm{RO}^{\text {hi }}$ TCM and CD45RO ${ }^{\text {low }}$ TCM subpopulations (Fig. 1c and d). Geometric mean florescence intensity (MFI) of CD95 was considered the criterion for expression level at the individual cell level. Each MFI was normalized to the MFI of unstained cells.

\section{Statistical analysis}

The nonparametric Mann-Whitney U and KruskalWallis $\mathrm{H}$ tests were used to identify statistically significant differences in subset frequencies between different patient subgroups. Correlations between the prevalence of each memory $\mathrm{T}$ cell subset and tumor size were determined by calculating Spearman's rank correlation. SPSS 20 software (IBM Corp., Armonk, N.Y., USA) was used for all statistical analyses, and $P$ values less than 0.05 (two-tailed) were considered significant. GraphPad 
Table 1 Clinical and pathological characteristics of patients with breast cancer

Characteristics
Age (years)
Lymph node status
Free
Involved
N0
N1
N2
N3
Stage
I
II
III
Tumor size
T1 ( 2 )
T2 (2-5)
Unreported
Tumor type
Invasive ductal carcinoma (IDC)
Invasive lobular carcinoma (ILC)
Invasive medullary carcinoma (IMC)
Mixed IDC and ILC
Unreported
Well differentiated (I)
Moderately differentiated (II)
Poorly differentiated (III)
Unreported

\section{Estrogen receptor (ER)}

Negative

Positive

Unreported

\section{Progesterone receptor (PR)}

Negative

Positive

Unreported

\section{Her2 expression}

Negative

Positive

Equivocal

Unreported

Invasion

Lymphatic invasion

$\frac{\text { Value }}{48.9 \pm 1.55}$

$29(55.77 \%)$

$23(44.23 \%)$

$15(28.85 \%)$

$9(17.31 \%)$

$4(7.69 \%)$

$9(17.31 \%)$

$29(55.77 \%)$

14 (26.92\%)

$20(41.66 \%)$

$28(58.33 \%)$

4

$41(82.00 \%)$

$3(6.00 \%)$

$4(8.00 \%)$

$2(4.00 \%)$

2

$5(11.63 \%)$

$27(62.79 \%)$

$11(25.58 \%)$

9

$37(82.22 \%)$

$8(17.77 \%)$

7

$11(25.58 \%)$

$32(74.42 \%)$

9

$30(58.82 \%)$

$15(29.41 \%)$

$6(11.76 \%)$

1

$11(21.57 \%)$
$24(46.15 \%)$
Table 1 Clinical and pathological characteristics of patients with breast cancer (Continued)

\begin{tabular}{ll}
\hline Characteristics & Value \\
\hline Positive & 40 (78.43\%) \\
Unreported & 1 \\
Vascular invasion & \\
Negative & $11(21.57 \%)$ \\
Positive & $40(78.43 \%)$ \\
Unreported & 1 \\
Perineural invasion & \\
Negative & $5(9.80 \%)$ \\
Positive & $46(90.20 \%)$ \\
Unreported & 2 \\
\hline
\end{tabular}

*All percentages are valid percent values. Missing data were excluded from the calculations

Prism 6 software (GraphPad Software, Inc., USA) was used to draw the graphs.

\section{Results}

After the diagnosis of $\mathrm{BC}$ was confirmed by pathological examination, 52 untreated patients with $\mathrm{BC}$ (mean age $=$ $48.9 \pm 1.55$ years) were recruited into the study. According to the pathology reports, 23 out of 52 LNs were involved (44.23\%). Most patients were in stage II (29/52, $55.77 \%$ ), and in most, the tumor type was invasive ductal carcinoma (IDC, 41/50, 82.0\%). The main clinical and pathological characteristics of the patients are summarized in Table 1.

\section{Frequency of $\mathrm{CD}^{+}$memory $\mathrm{T}$ cell subsets in tumor- draining lymph nodes}

The average frequency of different memory $\mathrm{T}$ cell subtypes in the $\mathrm{CD} 8^{+}$lymphocyte population along with mean expression of CD95 on the surface of these cells are reported in Table 2. As shown, $8.43 \pm 0.49$ of the lymphocytes in TDLNs of patients with BC were CD8positive. In this group, more than $47 \%(47.65 \pm 2.66 \%)$ of the cells expressed CD45RO, a marker of the memory T cell phenotype.

\section{Memory $\mathrm{CD}^{+} \mathrm{T}$ cell subsets in patients with different clinical and pathological characteristics}

In the next step, we investigated the association of memory $\mathrm{CD}^{+}{ }^{+}$subsets and naive $\mathrm{CD} 8^{+}$cells with different clinical and pathological parameters. Statistical analysis showed that the percentage of $\mathrm{CD}^{+} 5^{+} \mathrm{CD}^{+}$and $\mathrm{CD} 45 \mathrm{RO}^{\text {low }} \mathrm{CD}^{+}$cells was significantly higher in involved lymph nodes comparing to tumor-free ones $(P=$ 0.036 and $P=0.048$, respectively). The percentage of $\mathrm{CD} 45 \mathrm{RO}^{+} \mathrm{CD}^{+}$cells was also higher in patients with larger tumors (T2 vs. T1, $P=0.035$ ). While the frequency of $\mathrm{CD}^{+}$lymphocytes was significantly lower in 
Table 2 Frequency of different memory $\mathrm{CD}^{+} \mathrm{T}$ cell subsets in tumor-draining lymph nodes of patients with breast cancer

\begin{tabular}{|c|c|c|c|c|c|}
\hline Subset & Markers & Min & Max & Median & Mean \pm SEM \\
\hline $\mathrm{CD8}^{+}$lymphocytes & $\mathrm{CD}^{+}$ & 2.7 & 18.19 & 7.57 & $8.43 \pm 0.49$ \\
\hline $\mathrm{CD}_{45 \mathrm{RO}^{+} \mathrm{CD} 8^{+}}$ & $\mathrm{CD}^{+} \mathrm{CD} 45 \mathrm{RO}^{+}$ & 18.34 & 89.77 & 45.38 & $47.65 \pm 2.66$ \\
\hline $\mathrm{CD}^{2} 5 \mathrm{RO}^{\mathrm{hi}}$ & $\mathrm{CD} 8^{+} \mathrm{CD} 45 \mathrm{RO}^{\mathrm{hi}}$ & 5.58 & 66.50 & 28.38 & $29.10 \pm 2.05$ \\
\hline $\mathrm{CD} 45 \mathrm{RO}^{\text {low }}$ & $\mathrm{CD}^{+} \mathrm{CD} 45 \mathrm{RO}^{\text {low }}$ & 8.09 & 37.55 & 18.44 & $18.66 \pm 0.89$ \\
\hline TCM & $\mathrm{CD}^{+} \mathrm{CCR7}^{+} \mathrm{CD} 45 \mathrm{RO}^{+} \mathrm{CD}_{95}{ }^{+}$ & 8.91 & 75.12 & 31.42 & $33.84 \pm 2.16$ \\
\hline $\mathrm{CD} 5 \mathrm{RO}^{\mathrm{hi}}$ & $\mathrm{CD}^{+}{ }^{+} \mathrm{CCR}^{+} \mathrm{CD} 4 \mathrm{RO}^{\mathrm{hi}} \mathrm{CD} 5^{+}$ & 3.97 & 57.80 & 20.21 & $22.49 \pm 1.83$ \\
\hline CD45RO low & $\mathrm{CD}^{+} \mathrm{CCR}^{+} \mathrm{CD} 45 \mathrm{RO}^{\mathrm{low}} \mathrm{CD} 5^{+}$ & 3.0 & 30.28 & 11.89 & $13.61 \pm 0.84$ \\
\hline CD8 ${ }^{+}$TEM & $\mathrm{CD}^{+} \mathrm{CCR}^{-} \mathrm{CD}^{-} 5 \mathrm{RO}^{+} \mathrm{CD} 5^{+}$ & 1.75 & 23.28 & 7.98 & $9.24 \pm 0.78$ \\
\hline $\mathrm{CD}^{+} \mathrm{TSCM}^{-}$ & $\mathrm{CD}^{+} \mathrm{CCR7}^{+} \mathrm{CD} 45 \mathrm{RO}^{-} \mathrm{CD} 5^{+}$ & 1.08 & 41.51 & 5.79 & $9.40 \pm 1.37$ \\
\hline T Naive & $\mathrm{CD}^{+} \mathrm{CCR7}^{+} \mathrm{CD} 45 \mathrm{RO}^{-} \mathrm{CD} 5^{-}$ & 0.18 & 77.44 & 43.55 & $41.89 \pm 2.89$ \\
\hline $\mathrm{CD} 5^{+} \mathrm{CD}^{+}$ & $\mathrm{CD}^{+} \mathrm{CD} 5^{+}$ & 15.82 & 91.35 & 54.93 & $54.90 \pm 2.89$ \\
\hline $\mathrm{CCR7}^{+} \mathrm{CD}^{+}$ & $\mathrm{CD}^{+} \mathrm{CCR}^{+}$ & 74.33 & 97.84 & 91.62 & $89.70 \pm 0.82$ \\
\hline \multicolumn{6}{|c|}{ Mean expression of $\mathrm{CD} 95$ on different memory $\mathrm{CD}^{+} \mathrm{T}$ cell subsets (based on MFI) } \\
\hline TCM & $\mathrm{CD}^{+} \mathrm{CCR7}^{+} \mathrm{CD} 45 \mathrm{RO}^{+} \mathrm{CD} 5^{+}$ & 19.88 & 98.46 & 58.91 & $60.55 \pm 2.90$ \\
\hline CD45RO ${ }^{\mathrm{hi}}$ & $\mathrm{CD}^{+} \mathrm{CCR}^{+} \mathrm{CD} 4 \mathrm{RO}^{\mathrm{hi}} \mathrm{CD} 5^{+}$ & 28.98 & 134.80 & 75.18 & $76.96 \pm 3.58$ \\
\hline CD45RO low & $\mathrm{CD}^{+} \mathrm{CCR}^{+} \mathrm{CD} 45 \mathrm{RO}^{\mathrm{low}} \mathrm{CD} 5^{+}$ & 12.07 & 82.07 & 42.17 & $44.97 \pm 2.12$ \\
\hline TEM & $\mathrm{CD}^{+} \mathrm{CCR7}^{-} \mathrm{CD} 45 \mathrm{RO}^{+} \mathrm{CD} 5^{+}$ & 30.35 & 121.92 & 67.48 & $71.43 \pm 3.34$ \\
\hline TSCM & $\mathrm{CD}^{+} \mathrm{CCR7}^{+} \mathrm{CD} 4 \mathrm{RO}^{-} \mathrm{CD} 5^{+}$ & 5.61 & 84.95 & 22.89 & $27.80 \pm 2.03$ \\
\hline
\end{tabular}

*TCM T central memory; TEM T effector memory; TSCM T stem cell memory; TN T naive

patients of N1 (with 1-3 involved nodes) and N2 (with 3-9 involved nodes) compared to patients with free nodes ( $P=0.004$ and $P=0.025$, respectively).

\section{$\mathrm{CD}^{+}{ }^{\mathrm{TCM}}$ cells}

The total frequency of TCM with the $\mathrm{CD} 8^{+} \mathrm{CCR} 7{ }^{+} \mathrm{CD} 45 \mathrm{RO}^{+} \mathrm{CD} 95^{+}$phenotype was $33.84 \pm$ 2.16 in draining lymph nodes of patients with BC. We also investigated two different subsets with low and high CD45RO expression (Table 2). Our analysis showed that the frequency of total TCM cells and the subset with low CD45RO expression (CD45RO ${ }^{\text {low }} \mathrm{TCM}$ ) was significantly greater in involved nodes compared to tumor-free ones $(P=0.024$ and $P=0.017$, respectively; Fig. $2 \mathrm{a})$. Among patients in different pathological stages, CD95 expression (based on MFI) on the surface of TCM overall, and the CD45RO ${ }^{\text {hi }}$ TCM and CD45RO low TCM subsets, was higher only in patients with stage II compared to those with stage I disease $(P=0.004, P=0.015$ and $P=0.001$, respectively). In addition, the expression of CD95 on TCM was higher in TDLNs of patients with moderately differentiated tumor cells (grade II) compared with those with well-differentiated tumors (grade I, $P=0.019$ ). Regarding the number of involved lymph nodes, CD95 expression on TCM, CD45RO ${ }^{\text {hi }}$ and CD45RO ${ }^{\text {low }}$ TCM subsets was notably higher in patients with N1 disease compared to the node-free group $(P<$ $0.0001, P=0.002$ and $P<0.001$, respectively). Mean fluorescence intensity for CD95 on TCM cells was also greater in the $\mathrm{N} 3$ group $(P=0.037)$ compared to the N0 group. Furthermore, the percentage of CD45RO ${ }^{\text {hi }} \mathrm{TCM}$ cells was also greater in patients with larger tumor sizes (T2 vs. T1; $P=0.038$ ).

\section{CD8 ${ }^{+}$TEM cells}

Approximately $9 \%$ of $\mathrm{CD}^{+}$cells $(9.24 \pm 0.78 \%)$ in draining LNs of patients with $\mathrm{BC}$ had the effector memory phenotype $\left(\mathrm{CD}^{+} \mathrm{CCR}^{-} \mathrm{CD} 45 \mathrm{RO}^{+} \mathrm{CD} 95^{+}\right)$. Analysis of CD95 expression on TEM cells in patients with different clinical and pathological characteristics indicated higher expression of this molecule in $\mathrm{N} 1$ patients compared to node-free patients $(P=0.020)$.

\section{$\mathrm{CD}^{+}$TSCM cells}

The frequency of the $\mathrm{CD} 8^{+} \mathrm{CCR} 7^{+} \mathrm{CD} 45 \mathrm{RO}^{-} \mathrm{CD} 95^{+}$ phenotype, considered here to reflect TSCM cells, was $9.40 \pm 1.37 \%$. Although the frequencies of these cells did not differ significantly among patients with different clinical and pathological characteristics, mean expression of CD95 (based on MFI) on the surface of TSCM showed an increase in patients with stage II $(P=0.012)$ compared to those in stage I. The expression of CD95 on these cells was also greater in TDLNs of N1 patients compared to node-free patients (N0, $P=0.003$ ).

\section{Naive $\mathrm{CD}^{+}$lymphocytes}

In addition to memory $\mathrm{CD}^{+}$lymphocytes, we also determined the percentage of lymphocytes with the naive 


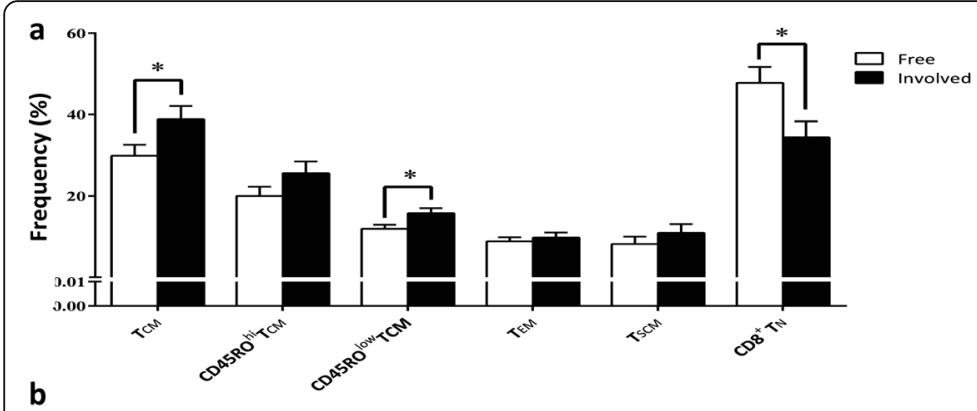

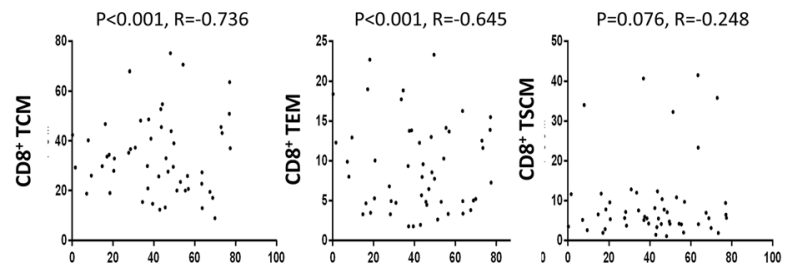

Naïve CD8+ lymphocytes
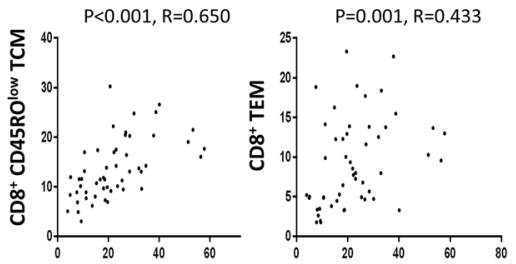

CD8 $^{+}$CD45RO ${ }^{\text {hi }}$ TCM

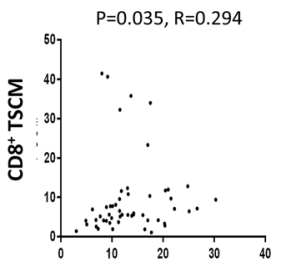

CD8 ${ }^{+}$CD45RO ${ }^{\text {low }}$ TCM

Fig. 2 Frequency of memory cells in tumor-draining lymph nodes of patients with different nodal status as well as their correlation. The percentages of different CD8 ${ }^{+}$memory cell subsets in draining lymph nodes of breast cancer patients with different statuses of lymph nodes involvement. (a) The frequency of TCM and their CD45RO ${ }^{\text {low }}$ subset were significantly higher in tumor-involved lymph nodes. Part (b) shows significant correlations among different $\mathrm{CD}^{+}$lymphocyte subsets. Data are presented as the mean \pm SEM. ${ }^{*}$ Significant difference at the 0.05 level (two-tailed)

phenotype $\left(\mathrm{CCR}^{+} \mathrm{CD} 45 \mathrm{RO}^{-} \mathrm{CD} 95^{-}\right)$in TDLNs. The percentage of naive $\mathrm{CD}^{+} \mathrm{T}$ cells was significantly lower in tumor-involved lymph nodes compared to tumor-free ones $(P=0.022$, Fig. $2 \mathrm{a})$.

\section{Correlations among frequencies of different $\mathrm{CD} 8^{+}$ lymphocyte subsets}

We also investigated the correlations among different subsets, and between subsets and patients' age, with the Spearman correlation test (Fig. 2b). The results showed that the percentage of naive cells had a strong negative correlation with TCM $(P<0.001, \mathrm{R}=-0.736)$, their $\mathrm{CD}_{45 \mathrm{RO}^{\text {hi }}}(\mathrm{P}<0.001, \mathrm{R}=-0.773)$ and $\mathrm{CD} 45 \mathrm{RO}^{\text {low }}(\mathrm{P}<$ $0.001, \mathrm{R}=-0.682)$ subsets, and TEM cells $(\mathrm{P}<0.001$, $\mathrm{R}=-0.645)$. The percentage of $C D 45 \mathrm{RO}^{\text {low }} \mathrm{TCM}$ cells had a positive correlation with $C D 45 R^{\text {hi }}$ TCM $(\mathrm{P}<$ $0.001, \mathrm{R}=0.650)$ and TSCM $(P=0.035, \mathrm{R}=0.294)$ subsets, and the percentage of CD45RO ${ }^{\text {hi }}$ TCM cells correlated strongly with TEM cells $(P=0.001, \mathrm{R}=0.433)$. We also observed a positive association between age and the frequency of $\mathrm{CD}^{2} 5 \mathrm{RO}^{+} \mathrm{CD}^{+} \quad(P=0.042, \mathrm{R}=0.283)$, TCM $(P=0.022, \mathrm{R}=0.318)$ and TSCM $(P=0.049, \mathrm{R}=$ $0.275)$ subsets. Conversely, a negative correlation was observed between age and the frequency of TN $(P=$ $0.025, \mathrm{R}=-0.0310)$.

\section{Discussion}

To our knowledge the present study is the first to investigate the presence and associations of $\mathrm{CD}^{+}$memory $\mathrm{T}$ cell subsets in TDLNs from patients with BC. On average, $8 \%$ of lymphocytes were positive for CD8, representing cytotoxic lymphocytes; almost half of them expressed the CD45RO memory cell marker (Table 2). The frequency of these memory cells did not differ among patients with different clinical and pathological characteristics; however, the frequencies of memory subpopulations, TCM and its subset with low CD45RO expression were significantly higher in tumor-involved lymph nodes.

There is a general consensus that in the context of the antitumor immune response, the frequency of $\mathrm{CD}^{+}$lymphocytes and their memory $\mathrm{T}$ cell subsets correlates positively with smaller tumor size, lower disease stages, less lymph node involvement, and a generally better prognosis or survival in most types of cancer, e.g. breast carcinoma $[14,16-22]$. $\mathrm{CD}^{+}$lymphocytes are assumed to mediate tumor rejection through the direct killing of transformed cells. Consistently, we observed a reduction in the frequency of total $\mathrm{CD}^{+}$lymphocytes and their naive subset along with tumor dissemination to draining lymph nodes. On the other hand, an increased frequency of $\mathrm{CD}_{4} 5 \mathrm{RO}^{+} \mathrm{CD}^{+}$lymphocytes was shown to be associated with larger tumor size. Similar results were obtained in our previous study regarding some $\mathrm{CD}^{+}$memory subsets [13]. In line with our observation, Feuerer and colleagues also found that the number of memory cells $\left(\mathrm{CD}^{+} / \mathrm{CD}^{+}\right.$ $\mathrm{CD}_{4} 5 \mathrm{RO}^{+}$) in the bone marrow of patients with $\mathrm{BC}$ increased in parallel with tumor cell metastases to the bone 
marrow [23, 24]. This may simply reflect an immune system attempt to provide an antitumor immune response after encountering antigens.

It is now well documented that the CD45RO marker cannot unequivocally define the memory $\mathrm{T}$ cell phenotype, since other effectors such as B and NK cell subsets also express CD45RO. In addition, different subtypes of memory cells have different functionality and homing properties. Despite the well-known role of memory cells in the defense against tumors, the role of their subsets has been rarely studied in cancer. Hence, we also investigated different subpopulations of $\mathrm{CD}^{+}$memory $\mathrm{T}$ cells in TDLNs of patients with BC.

Memory $\mathrm{CD}^{+} \mathrm{T}$ cells are conventionally divided to two main subsets: TCM and TEM. While TCM cells express the CCR7 homing receptor and show less differentiation, higher self-renewal potential and increased proliferation, TEM cells are commonly characterized by a phenotype more similar to that of effector cells, i.e. high cytotoxicity, rapid effector function and high IFNY secretion $[25,26]$. We observed that more than $33 \%$ of $\mathrm{CD}^{+}$lymphocytes in TDLNs of patients with BC had the TCM phenotype, versus $9 \%$ of cells with the TEM phenotype. The lower frequency of TEM cells is consistent with the migration of these cells to inflammatory sites, as also observed for $\mathrm{CD} 4^{+}$TEM in our previous study [13]. A predominant frequency of TEM cells in tumor microenvironments has been reported in different murine and human tumor models [25]. In our patients there were no remarkable differences in the percentages of TEM cells in relation with different clinical and pathological characteristics; however, we observed that the total percentage of TCM cells and their CD45RO ${ }^{\text {low }}$ subset was much higher in involved nodes compared to tumor-free ones. Similar results were reported for $\mathrm{CD} 4^{+}$ lymphocytes in our previous study of $\mathrm{CD} 4^{+} \mathrm{TCM}$ subsets [13]. Considering the fact that CD45RO expression increases in parallel with differentiation in memory cells, these findings along with the increased expression of CD95 on TCM and their subsets in patients with advanced tumors (i.e. higher stage, higher grade, and more tumor-involved nodes) suggest that in $\mathrm{BC}$, although the immune system tries to provide a pool of effective memory cells against the tumor, interactions with, or signals from, transformed cells and the tumor microenvironment lead to changes that diminish the host's ability to eradicate the tumor. Concordant with this hypothesis, a number of earlier studies found that in growing tumors, immune cells in the tumor milieu, draining lymph nodes and peripheral blood from patients with $\mathrm{BC}$ are often functionally impaired or have regulatory phenotypes [27-31]. In addition to the fact that the CD45RO marker is also highly expressed on regulatory $\mathrm{T}$ cells [32], it has also been shown that by regulating the threshold of sensitivity, CD45 expression regulates cellular responses [33]. Accordingly, the failure in tumor immunological responses appears to be partly due to the suppression of memory cell differentiation or function as the disease progresses.

Our findings also provide the first evidence, to our knowledge, of the presence of a new subset of memory $\mathrm{CD}^{+}$cells, TSCM, in TDLNs of patients with BC. These cells are known to be highly proliferative, self-renewing, and multipotent, and to have the potential ability to differentiate into other memory subsets; accordingly, they have been named memory stem cells. In the present study, TSCM cells $\left(\mathrm{CD} 8^{+} \mathrm{CCR} 7^{+} \mathrm{CD} 45 \mathrm{RO}^{-} \mathrm{CD} 95^{+}\right)$represented more than $9 \%$ of $\mathrm{CD}^{+}$cells; however, the frequency of these cells did not differ significantly in women with different clinical and pathological characteristics. Nevertheless, we observed that mean expression of CD95 on the surface of TSCM was higher in patients with higher-stage $\mathrm{BC}$ and lymph node involvement. Regarding $\mathrm{CD}^{+}{ }^{+} \mathrm{TSCM}$, we observed that they were more frequent in tumor-involved lymph nodes and in patients with advanced-stage disease [13]. Few studies to date have aimed to investigate the role of TSCM in cancer, but some recent work, focused on the distribution and function of TSCM in antitumor immune responses, showed an increased frequency of $\mathrm{CD}_{4}^{+}$and $\mathrm{CD} 8^{+}$ TSCM cells in blood and lymph nodes from patients with non-small-cell lung cancer [34], and in patients with acute-phase adult T cell leukemia, in which TSCM are considered to be a reservoir for the HTLV-1 virus [35].

\section{Conclusion}

Our data constitute evidence that the frequencies of $\mathrm{CD}^{+}$lymphocytes as well as their TSCM subsets do not change significantly in draining lymph nodes of patients with $\mathrm{BC}$. However, the frequency of $\mathrm{CD}^{+}$memory subsets with low CD45RO expression was higher in tumoraffected nodes. These observations provide some support for our previous hypothesis that in $\mathrm{BC}$, following constant, long-term exposure to tumor antigens, the patient's immune system attempts to provide a pool of effective memory cells. Nevertheless, tumor-derived suppressive factors appear to block memory cell differentiation in the early stages of the disease $\left(\mathrm{CD} 45 \mathrm{RO}^{\text {low }}\right)$. Identifying the molecular and cellular mechanisms behind this suppression holds the potential to provide invaluable tools for adoptive $\mathrm{T}$ cell therapies in cancer.

\section{Acknowledgements}

We thank K. Shashok (AuthorAID in the Eastern Mediterranean) for editing the manuscript.

Availability of data and material

The datasets used and/or analyzed during the current study are available from the corresponding author on reasonable request. 


\section{Authors' contributions}

ZF and AG contributed to the conception of the study. YV and MB obtained the data. ZF and $\mathrm{V}$ analyzed the data, interpreted them and provided a draft for the article. All of the authors read and approved the final manuscript.

\section{Funding}

The present study was financially supported by grants from Shiraz University of Medical Sciences, Shiraz, Iran [Grant No. 95-11340] and Shiraz Institute for Cancer Research [ICR-100-500]. The funding bodies supported the project by covering the cost of reagents and consumable materials only. The funders had no role in study design, data collection and analysis, decision to publish, or preparation of the manuscript.

\section{Ethics approval and consent to participate}

All procedures involving human participants were in accordance with the ethical standards of the Ethical Committee of Shiraz University of Medical Sciences (IR.SUMS.REC.1395.S130) and with the 1964 Helsinki declaration and its later amendments or comparable ethical standards. Informed consent was also verbally obtained from all patients following assignment a written consent for surgical operations.

\section{Consent for publication}

Not applicable.

\section{Competing interests}

The authors declare that they have no competing interests.

\section{Author details}

'Shiraz Institute for Cancer Research, School of Medicine, Shiraz University of Medical Sciences, P.O. Box: 71345-1798, Shiraz, Iran. ${ }^{2}$ Department of Pathology, Shiraz Central Hospital, Shiraz, Iran.

\section{Received: 4 August 2019 Accepted: 4 March 2020}

Published online: 30 March 2020

\section{References}

1. Murata K, Tsukahara T, Torigoe T. Cancer immunotherapy and immunological memory. Nihon Rinsho Meneki Gakkai Kaishi. 2016;39(1):1822.

2. Sarkar I, Pati S, Dutta A, Basak U, Sa G. T-memory cells against cancer: remembering the enemy. Cell Immunol. 2019;338:27-31.

3. Wherry EJ, Teichgraber V, Becker TC, Masopust D, Kaech SM, Antia R, von Andrian $\mathrm{UH}$, Ahmed R. Lineage relationship and protective immunity of memory CD8 T cell subsets. Nat Immunol. 2003;4(3):225-34

4. Gattinoni L, Klebanoff CA, Restifo NP. Pharmacologic induction of CD8+ T cell memory: better living through chemistry. Sci Transl Med. 2009;1(11): 11 ps12.

5. Gattinoni L, Speiser DE, Lichterfeld M, Bonini C. T memory stem cells in health and disease. Nat Med. 2017;23(1):18-27.

6. Ribeiro SP, Milush JM, Cunha-Neto E, Kallas EG, Kalil J, Somsouk M, Hunt PW, Deeks SG, Nixon DF, SenGupta D. The CD8(+) memory stem T cell (T (SCM)) subset is associated with improved prognosis in chronic HIV-1 infection. J Virol. 2014:88(23):13836-44.

7. Flynn JK, Gorry PR. T cell therapies-are T memory stem cells the answer? Ann Transl Med. 2015;3(17):251

8. Biasco L, Scala S, Basso Ricci L, Dionisio F, Baricordi C, Calabria A, Giannelli S, Cieri N, Barzaghi F, Pajno R, et al. In vivo tracking of $T$ cells in humans unveils decade-long survival and activity of genetically modified T memory stem cells. Sci Transl Med. 2015;7(273):273ra213.

9. Klebanoff CA, Gattinoni L, Restifo NP. Sorting through subsets: which T-cell populations mediate highly effective adoptive immunotherapy? J Immunother. 2012;35(9):651-60.

10. Reiser J, Banerjee A. Effector, memory, and dysfunctional CD8(+) T cell fates in the antitumor immune response. J Immunol Res. 2016;2016:8941260.

11. Klebanoff CA, Gattinoni L, Torabi-Parizi P, Kerstann K, Cardones AR, Finkelstein SE, Palmer DC, Antony PA, Hwang ST, Rosenberg SA, et al. Central memory self/tumor-reactive CD8+ T cells confer superior antitumor immunity compared with effector memory T cells. Proc Natl Acad Sci U S A. 2005;102(27):9571-6
12. Maimela NR, Liu S, Zhang Y. Fates of CD8+ T cells in tumor microenvironment. Comput Struct Biotechnol J. 2019;17:1-13.

13. Vahidi Y, Faghih Z, Talei AR, Doroudchi M, Ghaderi A. Memory CD4(+) T cell subsets in tumor draining lymph nodes of breast cancer patients: a focus on T stem cell memory cells. Cell Oncol (Dordr). 2018;41(1):1-11.

14. Ahmadvand S, Faghih Z, Montazer M, Safaei A, Mokhtari M, Jafari P, Talei AR, Tahmasebi S, Ghaderi A. Importance of CD45RO+ tumor-infiltrating lymphocytes in post-operative survival of breast cancer patients. Cell Oncol (Dordr). 2019;42(3):343-56

15. Edge SB, Compton CC. The American joint committee on Cancer: the 7th edition of the AJCC cancer staging manual and the future of TNM. Ann Surg Oncol. 2010;17(6):1471-4.

16. Yajima R, Yajima T, Fujii T, Yanagita Y, Fujisawa T, Miyamoto T, Tsutsumi S, lijima M, Kuwano $\mathrm{H}$. Tumor-infiltrating CD45RO(+) memory cells are associated with a favorable prognosis breast cancer. Breast Cancer. 2016; 23(4):668-74.

17. Oberg A, Samii S, Stenling R, Lindmark G. Different occurrence of CD8+, CD45R0+, and CD68+ immune cells in regional lymph node metastases from colorectal cancer as potential prognostic predictors. Int J Color Dis. 2002;17(1):25-9.

18. Djenidi F, Adam J, Goubar A, Durgeau A, Meurice G, de Montpreville V Validire P, Besse B, Mami-Chouaib F. CD8+CD103+ tumor-infiltrating lymphocytes are tumor-specific tissue-resident memory $T$ cells and a prognostic factor for survival in lung cancer patients. J Immunol. 2015; 194(7):3475-86

19. Dudley ME, Yang JC, Sherry R, Hughes MS, Royal R, Kammula U, Robbins PF, Huang J, Citrin DE, Leitman SF, et al. Adoptive cell therapy for patients with metastatic melanoma: evaluation of intensive myeloablative chemoradiation preparative regimens. J Clin Oncol. 2008;26(32):5233-9.

20. Galon J, Costes A, Sanchez-Cabo F, Kirilovsky A, Mlecnik B, Lagorce-Pages C, Tosolini M, Camus M, Berger A, Wind P, et al. Type, density, and location of immune cells within human colorectal tumors predict clinical outcome. Science. 2006;313(5795):1960-4.

21. Kmiecik J, Poli A, Brons NH, Waha A, Eide GE, Enger PO, Zimmer J, Chekenya M. Elevated CD3+ and CD8+ tumor-infiltrating immune cells correlate with prolonged survival in glioblastoma patients despite integrated immunosuppressive mechanisms in the tumor microenvironment and at the systemic level. J Neuroimmunol. 2013;264(1-2):71-83.

22. Mahmoud SM, Paish EC, Powe DG, Macmillan RD, Grainge MJ, Lee AH, Ellis IO, Green AR. Tumor-infiltrating CD8+ lymphocytes predict clinical outcome in breast cancer. J Clin Oncol. 2011;29(15):1949-55.

23. Schirrmacher $V$, Feuerer $M$, Beckhove $P$, Ahlert $T$, Umansky V. T cell memory, anergy and immunotherapy in breast cancer. J Mammary Gland Biol Neoplasia. 2002;7(2):201-8.

24. Feuerer M, Rocha M, Bai L, Umansky V, Solomayer EF, Bastert G, Diel IJ, Schirrmacher $V$. Enrichment of memory $T$ cells and other profound immunological changes in the bone marrow from untreated breast cancer patients. Int J Cancer. 2001;92(1):96-105.

25. Sallusto F, Geginat J, Lanzavecchia A. Central memory and effector memory T cell subsets: function, generation, and maintenance. Annu Rev Immunol. 2004:22:745-63.

26. Klebanoff CA, Gattinoni L, Restifo NP. CD8+ T-cell memory in tumor immunology and immunotherapy. Immunol Rev. 2006;211(1):214-24.

27. Mehdipour F, Razmkhah M, Hosseini A, Bagheri M, Safaei A, Talei AR, Ghaderi A. Increased B regulatory phenotype in non-metastatic lymph nodes of node-positive breast Cancer patients. Scand J Immunol. 2016;83(3): 195-202.

28. Faghih Z, Erfani N, Haghshenas MR, Safaei A, Talei AR, Ghaderi A. Immune profiles of CD4+ lymphocyte subsets in breast cancer tumor draining lymph nodes. Immunol Lett. 2014;158(1-2):57-65.

29. Razmkhah M, Jaberipour M, Erfani N, Habibagahi M, Talei AR, Ghaderi A. Adipose derived stem cells (ASCs) isolated from breast cancer tissue express IL-4, IL-10 and TGF-beta1 and upregulate expression of regulatory molecules on T cells: do they protect breast cancer cells from the immune response? Cell Immunol. 2011;266(2):116-22.

30. Faghih Z, Rezaeifard S, Safaei A, Ghaderi A, Erfani N. IL-17 and IL-4 producing CD8+ T cells in tumor draining lymph nodes of breast cancer patients: positive association with tumor progression. Iran J Immunol. 2013; 10(4):193-204

31. Bates JP, Derakhshandeh $R$, Jones $L$, Webb TJ. Mechanisms of immune evasion in breast cancer. BMC Cancer. 2018;18(1):556. 
32. Booth NJ, McQuaid AJ, Sobande T, Kissane S, Agius E, Jackson SE, Salmon M, Falciani F, Yong K, Rustin MH, et al. Different proliferative potential and migratory characteristics of human $\mathrm{CD} 4+$ regulatory $T$ cells that express either CD45RA or CD45RO. J Immunol. 2010;184(8):4317-26.

33. Liu Z, Dawes R, Petrova S, Beverley PC, Tchilian EZ. CD45 regulates apoptosis in peripheral T lymphocytes. Int Immunol. 2006;18(6):959-66.

34. Hong H, Gu Y, Sheng SY, Lu CG, Zou JY, Wu CY. The distribution of human stem cell-like memory T cell in lung Cancer. J Immunother. 2016;39(6):233-40

35. Nagai Y, Kawahara M, Hishizawa M, Shimazu Y, Sugino N, Fujii S, Kadowaki $\mathrm{N}$, Takaori-Kondo A. T memory stem cells are the hierarchical apex of adult T-cell leukemia. Blood. 2015;125(23):3527-35.

\section{Publisher's Note}

Springer Nature remains neutral with regard to jurisdictional claims in published maps and institutional affiliations.

Ready to submit your research? Choose BMC and benefit from:

- fast, convenient online submission

- thorough peer review by experienced researchers in your field

- rapid publication on acceptance

- support for research data, including large and complex data types

- gold Open Access which fosters wider collaboration and increased citations

- maximum visibility for your research: over $100 \mathrm{M}$ website views per year

At BMC, research is always in progress.

Learn more biomedcentral.com/submissions 